\title{
PEMANFAATAN PENGETAHUAN TRADISIONAL INDONESIA BERDASARKAN POTENSI DAERAH SEBAGAI MODAL PEMBANGUNAN
}

\author{
Heri Aryanto ${ }^{1}$
}

\begin{abstract}
Indonesia has ratified the Law No. 7 of 1994 corcerning The Establishment of the WTO following the TRIPS agreement, which govern the protection of intellectual property rights internationally. However, the concept of IPRs in TRIPS which agree to the concept of private property is absolutely contrary to the concept of communal ownership. This is understandable because the formulation of TRIPs based on the idea and urging the developed countries in response to the signing of the Convention on Biological Diversity in 1992 that could impede the access to the developed countries in taking advantage of the traditional knowledge of developing countries such as Indonesia, through biopiracy and misappropriate actions. Indonesia's efforts in protecting its traditional knowledge, among others, is to ratify the Nagoya Protocol which govern the protection of traditional knowledge associated with genetic resources. ,meanwhile Indonesia does not have a sui generis laws governing traditional knowledge. Therefore, in addition to the protection, utilization is also important thing to be done in order to protect traditional knowledge itself. Given that Indonesia has abundant biological and cultural biodiversity nationwide, then the utilization of traditional knowledge must be in synergy and harmony with the potential and characteristics of the regions, among others are human resources, natural resources, environment and infrastructures. These potentialities are the assets $l$ of Indonesian development if they could be properlu managed. (efficiently and effectively). The Utilization of traditional knowledge which based on this concept is actually coherent with the development guidelines endorsed by Law no. 17 of 2007 on National Long Term Development Plan 2005-2025.
\end{abstract}

Keywords: traditional knowledge, HKI, regional development

\begin{abstract}
Abstrak
Indonesia telah meratifikasi UU No. 7 tahun 1994 mengenai Pembentukan WTO berikut persetujuan TRIPs yang mengatur mengenai perlindungan HKI secara internasional. Namun, konsep HKI yang disepakati di dalam TRIPs merupakan konsep pemilikan pribadi secara mutlak yang bertentangan dengan konsep kepemilikan komunal. Hal ini dapat dipahami karena TRIPs dibentuk berdasarkan gagasan dan desakan negara maju sebagai reaksi atas

\footnotetext{
${ }^{1}$ Penulis adalah Mahasiswa Magister Hukum Hak Kekayaan Intelektual Universitas Indonesia. Alamat kontak: heritigro@gmail.com
} 
disepakatinya Convention on Biological Diversity pada tahun 1992 yang bisa menghambat akses negara-negara maju untuk memanfaatkan pengetahuan tradisional negara-negara berkembang seperti Indonesia melalui tindakan biopiracy maupun missappropriation. Upaya yang dilakukan Indonesia dalam melindungi pengetahuan tradisionalnya antara lain dengan meratifikasi Nagoya Protocol yang subtansinya mengatur mengenai perlindungan pengetahuan tradisional yang berkaitan dengan sumber daya genetik. Selebihnya, Indonesia tidak memiliki undang-undang sui generis yang mengatur mengenai pengetahuan tradisional. Oleh karenanya, selain upaya perlindungan, pemanfaatan juga penting untuk dilakukan dalam rangka perlindungan pengetahuan tradisional itu sendiri. Mengingat Indonesia memiliki keanekaragaman hayati dan hasanah budaya yang melimpah dan beragam di setiap daerah, maka pemanfaatan pengetahuan tradisional harus sinergi dengan potensi dan karakteristik yang dimiliki daerah antara lain sumber daya manusia, sumber daya alam, lingkungan dan infrastruktur. Potensi-potensi ini merupakan modal pembangunan Indonesia apabila potensi tersebut dapat dimanfaatkan secara tepat (efisien dan efektif) serta benar. Pemanfaatan pengetahuan tradisional berdasarkan konsep ini sejalan dengan arahan pembangunan yang dicanangkan oleh UU No. 17 tahun 2007 tentang Rencana Pembangunan Jangka Panjang Nasional 2005 - 2025.

Kata kunci: pengetahuan tradisional, HKI, pembangunan daerah

\section{Pendahuluan}

Lahirnya Organisasi Perdagangan Dunia atau World Trade Organization ("WTO") sebagai hasil putaran ke-8 Uruguay Round, telah memberikan dampak terhadap lahirnya persetujuan mengenai perdagangan yang terkait dengan aspek-aspek Hak Kekayaan Intelektual ("Agreement on Trade-Related Aspects of Intellectual Property Rights atau TRIPs"). Alasan yang dijadikan pertimbangan disepakatinya TRIPs sebagai bagian dari lampiran (annex) 1C Persetujuan Pembentukan WTO (Agreement Establishing the World Trade Organization) adalah karena Hak Atas Kekayaan Intelektual ("HKI") dapat berpengaruh terhadap perdagangan internasional ${ }^{2}$ yaitu HKI memainkan peranan yang penting dalam pengembangan ekonomi. ${ }^{3}$

TRIPs yang lahir bersamaan dengan pembentukan WTO di tahun 1994, telah menjadi instrumen hukum HKI yang disepakati secara internasional dan mengikat bagi negara-negara anggota yang menandatanganinya. Ruang lingkup HKI yang diatur dan menjadi domain perlindungan TRIPs antara lain : hak cipta dan hak terkait (copyright and related rights) dan hak kekayaan industri

\footnotetext{
${ }^{2}$ Ahmad Zen Umar Purba, "Perjanjian TRIPs dan Beberapa Isu Strategis", cetakan ke1, (Jakarta - Bandung: Badan Penerbit FH UI dan PT. Alumni, 2011), hal. 4.

${ }^{3}$ Keith E Maskus, “Intellectual Property Rights in Global Economy”, (Washington DC: Institute for International Economics, 2000), Pada Ahmad Zen Umar Purba, Ibid.
} 
(industrial property rights) ${ }^{4}$ yang meliputi merek dagang (trademark), indikasi geografis (geographical indication), desain industri (indutsrial design), paten (patent), desain tataletak sirkuit terpadu (layout-designs (topographies) of integrated circuit), rahasia dagang (undisclosed information), dan pengendalian praktek-praktek persaingan curang dalam perjanjian lisensi (control of anti-competitive practices in contractual licences. ${ }^{5}$

Masuknya HKI ke dalam pembahasan pembentukan WTO merupakan hasil desakan negara-negara maju terutama Amerika Serikat yang mengusulkan "Proposal for Negotiations on Trade-Related Aspects of Intellectual Property Rights" dan Uni Eropa yang mengusulkan "Proposal for Guidelines and Objectives". Kedua proposal tersebut merupakan strategi sekaligus keinginan negara-negara maju untuk melindungi kepentingan mereka di bidang HKI. ${ }^{6}$ Dengan kata lain, lahirnya TRIPs sebenarnya merupakan bentuk refleksi kemenangan perusahaan-perusahaan dari negara-negara industri terutama perusahaan-perusahaan Amerika Serikat dan Uni Eropa. ${ }^{7}$ Hal ini tergambarkan di Amerika Serikat, dimana sesungguhnya yang hendak dilindungi oleh rezim HKI yang diusulkan Amerika Serikat adalah kepentingan ekonomi (kapital) dan bukan kepentingan individu sebagai pencipta atau inventor. ${ }^{8}$ Di negeri yang terkenal sebagai pengagung HAM ini, justru kreatifitas dari orang kulit hitam kurang mendapat perlindungan dibandingan dengan pemilik modal dari kalangan kulit putih. ${ }^{9}$

Di pihak lain, kehadiran negara-negara berkembang di forum pembentukan WTO dan kemudian secara "terpaksa" menandatangani persetujuan TRIPs tersebut, tidak lain merupakan sikap kegelisahan dilematis. Di satu sisi, apabila negara-negara berkembang tidak ikut menandatangani Persetujuan Pembentukan WTO dan TRIPs, maka mereka akan merugi secara ekonomis karena negara-negara tersebut akan kehilangan fasilitas yang disediakan oleh WTO Agreement. Dan di sisi lain, apabila ikut namun lalai melaksanakannya, maka akan mendapatkan sanksi, khususnya dari negara-

4 OK Saidin, "Aspek Hukum Hak Kekayaan Intelektual (Intellectual Property Rights)", cetakan kesepuluh, (Jakarta: RajaGrapindo Persada, 2010), hal.29

${ }^{5}$ HKI yang disebut terakhir ini masih belum bisa diterima oleh negara-negara anggota sebagai bagian HKI yang harus dilindungi, karena menurut mereka persaingan curang tidak menunjukkan karakter yang jelas sebagai karya intelektual, lihat Rachmadi Usman, "Hukum Hak Atas Kekayaan Intelektual: Perlindungan dan Dimensi Hukumnya di Indonesia", (Bandung: Alumni, 2003). hal. 7. 2009), hal. 3-6

${ }^{6}$ Agus Sardjono, "Membumikan HKI di Indonesia", (Bandung: CV. Nuansa Aulia :

\footnotetext{
${ }^{7}$ Ahmad Zen Umar Purba, Op. Cit., hal. 10.

${ }^{8}$ Op Cit, hal. 9 .

${ }^{9}$ Ibid.
} 
negara maju baik secara bilateral maupun unilateral. ${ }^{10}$ Usulan negara-negara berkembang yang telah diusahakan melalui pembentukan New International Economic Order (NIEO) sejak tahun 1970-an terkait konsep kedaulatan atas sumber daya alam, investasi asing langsung (Foreign Direct Investment), dan alih teknologi dengan cara mengurangi perlindungan HKI di negara-negara berkembang $^{11}$, juga gagal disepakati dan bahkan ditolak oleh negara-negara maju di dalam forum internasional tersebut.

TRIPs disepakati sebagai standar minimum pelindungan HKI yang menempatkan kepemilikan pribadi secara mutlak. Sementara masyarakat di negara-negara berkembang masih menganut konsep kepemilikan komunal. Konsep kepemilikan ekslusif dalam TRIPs secara tidak langsung merupakan bentuk penolakan terhadap keinginan negara-negara berkembang terkait usulan pengurangan perlindungan HKI di negara-negara berkembang tersebut. Tertutupnya pintu untuk memberikan pengurangan perlindungan HKI di negara berkembang juga semakin nyata, setelah disepakati bahwa TRIPs harus diratifikasi tanpa reservasi, yang mana kondisi ini mengakibatkan negaranegara anggota yang hendak menerapkan TRIPs harus tunduk pada ketentuan bahwa hukum HKI yang dibuat di negara anggota tidak boleh mengatur lebih rendah dari ketentuan yang diatur di dalam TRIPs. Keringanan yang diberikan TRIPs kepada negara-negara berkembang hanya terkait dengan penundaan pemberlakuan TRIPs, sebagaimana yang diatur di dalam Ketentuan Peralihan Pasal 65 ayat (2) TRIPs yang menyebutkan: "A developing country Member is entitled to delay for a further period of four years the date of application, as defined in paragraph 1, of the provisions of this Agreement other than Articles 3, 4 and 5". Bagi negara-negara berkembang seperti Indonesia masa berlaku TRIPs secara efektif adalah per- tanggal 1 Januari $2000 .^{12}$

Kegagalan negara berkembang dalam memperjuangkan kepentingan mereka di forum internasional merupakan sebuah hasil dari kegigihan perlawanan negara-negara maju dalam upaya melindungi HKI mereka melalui konsep kepemilikan individu secara mutlak dan mengeyampingkan pengakuan kepemilikan komunal. TRIPs dibentuk tidak lama setelah disepakatinya secara internasional Convention on Biological Diversity 1992 (“CBD”) ${ }^{13}$ yang sangat pro terhadap kepentingan negara-negara berkembang dalam upaya melindungi keanekaragaman hayatinya. Kelahiran CBD sebenarnya tidak disukai dan tidak

${ }^{10}$ Ahmad Zen Umar Purba, Op. Cit., hal. 11.

${ }^{11}$ Lihat Ahmad Zen Umar Purba, Ibid., hal. 12 dan Agus Sardjono, Op. Cit., hal. 2.

12 Cita Citrawinda Priapantja, "Budaya Hukum Indonesia Menghadapi Globalisasi Perlindungan Rahasia Dagang di Bidang Farmasi”, Cetakan Ketiga, Jakarta : Chandra Pratama, 2005, hal. 4

${ }^{13}$ Konvensi ini telah diratifikasi oleh Indonesia melalui UU No. 5 Tahun 1994 tentang Pengesahan United Nations Convention Konvensi Perserikatan Bangsa-Bangsa Mengenai Keanekaragaman Hayati, Lembaran Negara Tahun 1994 Nomor 41, Tambahan Lembaran Negara Nomor 3556. 
didukung oleh negara-negara maju karena bagi negara-negara maju, pelaksanaan CBD tersebut akan menghalangi dan atau membatasi akses mereka ke sumber kekayaan hayati yang dimiliki oleh negara-negara berkembang yang notabene-nya sampai dengan detik ini masih mereka nikmati melalui rezim perlindungan paten. Amerika Serikat adalah salah satu negara maju yang menolak menandatangani CBD, dimana mereka beralasan bahwa pelaksanaan $\mathrm{CBD}$ akan mengurangi jaminan perlindungan hak paten warga negara Amerika Serikat. ${ }^{14}$

Kegagalan yang cukup penting lainnya adalah tidak dimasukkan dan diaturnya sumber daya genetik (genetic resources), foklor dan pengetahuan tradisional (traditional knowledge) sebagai bagian HKI di dalam TRIPs. Ketiga kekayaan tersebut, terutama pengetahuan tradisional merupakan kekayaan milik komunal yang telah lama eksis di dalam masyarakat tradisional di negara-negara berkembang secara turun temurun dan memenuhi kualifikasi untuk dilindungi sebagai HKI. Namun, kembali lagi ke awal tujuan pembentukan TRIPs yang merupakan hasil gagasan dan desakan negara-negara maju, dimana mereka tidak menginginkan adanya pembatasan akses untuk memanfaatkan lebih lanjut sumber daya genetik (genetic resources), foklor, dan pengetahuan tradisional (traditional knowledge) yang dimiliki oleh negara berkembang.

Terkait dengan pengetahuan tradisional, World Intellectual Property Organization ("WIPO") memberikan definisi pengetahuan tradisional sebagai berikut:

Knowledge, know-how, skills and practices that are developed, sustained and passed on from generation to generation within a community, often forming part of its cultural or spiritual identity. ${ }^{15}$

Sementara Prof. Agus Sadjono mendefinisikan pengetahuan tradisional sebagai pengetahuan yang dimiliki atau dikuasai dan digunakan oleh suatu komunitas, masyarakat, atau suku bangsa tertentu yang bersifat turun temurun dan berkembang sesuai dengan perubahan lingkungan. ${ }^{16}$ Dengan demikian secara sederhana pengetahuan tradisional digambarkan sebagai pengetahuan yang menjadi bagian identitas budaya atau spiritual dari suatu komunitas, masyarakat, atau suku bangsa tertentu yang didapatkan secara turun temurun.

Pengetahuan tradisional menurut WIPO diklasifikasikan menjadi: pengetahuan pertanian (agricultural knowledge), pengetahuan ilmiah (scientific knowledge), pengetahuan lingkungan (ecological knowledge), pengetahuan

\footnotetext{
${ }^{14}$ Agus Sardjono, "Hak Kekayaan Intelektual \& Pengetahuan Tradisional”, (Bandung: PT. Alumni, 2010), hal.45

15 World Intellectual Property Organization, diakses melalui <http://www.wipo.int/ tk/en/tk/index.html >, tanggal 26 Desember 2013.

${ }^{16}$ Agus Sardjono, Op. Cit., hal. 1.
} 
obat-obatan termasuk di dalamnya obat dan penyembuhan (medicines knowledge including related medicine and remedies), pengetahuan terkait keanekaragaman hayati (biodiversity-related knowledge), ekpresi foklor di bidang musik, tari, lagu, kerajinan tangan, unsur-unsur bahasa, dan benda budaya yang bergerak. ${ }^{17}$

Upaya untuk melindungi pengetahuan tradisional sebagai hak komunal memang mulai diulakukan melalui mekanisme WIPO yaitu dengan membentuk WIPO Fact-finding Missions (WIPO-FFMs) dan The WIPO Intergovernmental Committee (IGC) on Intellectual Property and Genetic Resources, Traditional Knowledge and Folklore ${ }^{18}$ maupun melalui pembentukan konvensi internasional yang melahirkan Nagoya Protocol on Access to Genetic Resources and the Fair and Equitable Sharing of Benefits Arising from their Utilization to the Convention on Biological Diversity yang diadopsi pada tanggal 29 Oktober 2010 di Nagoya. ${ }^{19}$ Namun demikian, negara-negara maju antara lain Perancis, Jepang, Belanda, Inggris, dan Amerika Serikat secara nyata menolak mengakui adanya kepemilikan komunal sebagai suatu kolektivitas, terutama ketika membicarakan The Draft United Nations Declaration on the Rights of Indigenous Peoples. ${ }^{20}$

Perlindungan terhadap pengetahuan tradisional dibutuhkan oleh negaranegara berkembang seperti Indonesia, setidaknya berdasarkan alasan ${ }^{21}:$ (1) Potensi pengetahuan tradisional Indonesia yang memiliki keuntungan ekonomis yang secara faktual banyak dimanfaatkan oleh negara-negara maju antara lain Amerika Serikat dan Jepang untuk industri obat-obatan dan kosmetika tanpa adanya pembagian keuntungan (benefit sharing) dengan Indonesia; (2) Ketidakadilan yang dialami oleh Indonesia sebagai negara berkembang atas kepemilikan pengetahuan tradisional yang tidak dilindungi sebagai HKI, sementara negara-negara-negara maju melakukan tindakan pencurian (biopiracy) dan penyalahgunaan (missappropriation) ${ }^{22}$ terhadap

17 Desi Churul Aini, Telaah Yuridis Ketentuan Perlindungan Pengetahuan Tradisional Dalam Hukum Internasional, Tesis Pascasarjana Hukum Universitas Indonesia, 2012, hal. 38-39.

$18<$ http://www.wipo.int/tk/en/igc/>, Op. Cit.

19 Ibid., <http://www.wipo.int/wipolex/en/other_treaties/details.jsp?treaty_id=311>, tanggal 26 Desember 2013.

${ }^{20}$ Agus Sardjono, Op. Cit., hal. 47.

${ }^{21}$ Ibid, hal. 3 .

22 Missappropriation didefinisikan sebagai penggunaan oleh pihak asing dengan mengabaikan hak-hak masyrakat lokal atas pengetahuan tradisional dan sumber daya hayati yang terkait, yang menjadi milik masyarakat yang bersangkutan. Istilah ini digunakan untuk menggambarkan suatu kondisi dimana Peneliti yang melakukan penelitian atas pengetahuan tradisional masyarakat lokal di negara-negara berkembang dan kemudian mengambil pengetahuan tradisional tersebut untuk diakui sebagai hasil invensinya dan didaftarkan di negaranya sebagai hak paten. Lihat Agus Sardjono, Ibid, hal. 11dan hal. 36. 
pengetahuan tradisional milik Indonesia; dan (3) Masyarakat lokal tidak mengetahui bahwa pengetahuan tradisional yang dimilikinya secara turun temurun memiliki manfaat ekonomis terutama pengetahuan tradisional mengenai obat-obatan sehingga pemerintah harus memberikan perlindungan kepada hak masyarakat lokal tersebut.

Namun demikian pemanfaatan pengetahuan tradisional juga harusnya menjadi bagian yang tidak terpisahkan dari upaya perlindungan pengetahuan tradisional. Hal ini mengingat Indonesia merupakan salah satu negara di dunia yang memiliki khasanah kebudayaan dan pengetahuan tradisional yang sangat beragam. ${ }^{23}$ Dari hasil inventarisasi dan penamaan pulau yang dilakukan oleh Direktorat Jenderal Kelautan Pesisir dan Pulau-Pulau Kecil Kementerian Kelautan dan Perikanan pada tahun 2010, Indonesia terdiri atas lebih dari 13.487 (tiga belas ribu empat ratus delapan puluh tujuh) pulau. Pulau yang satu dan yang lain dipisahkan oleh lautan sehingga membuahkan 47 (empat puluh tujuh) ekosistem yang sangat berbeda. ${ }^{24}$ Potensi ini merupakan sumber kekayaan yang melimpah dan akan mendatangkan keuntungan ekonomis apabila dimanfaatkan secara tepat dan benar oleh Pemerintah Pusat maupun Pemerintah Daerah.

Oleh karenanya, meskipun upaya untuk melindungi pengetahuan tradisional tersebut penting dan telah dilakukan dalam konteks intenasional melalui mekanisme WIPO dan dalam konteks nasional pun mulai dilakukan yaitu dengan membentuk UU No. 11 Tahun 2013 Tentang Pengesahan Nagoya Protocol On Access To Genetic Resources And The Fair And Equitable Sharing Of Benefits Arising From Their Utilization To The Convention On Biological Diversity (Protokol Nagoya Tentang Akses Pada Sumber Daya Genetik Dan Pembagian Keuntungan Yang Adil Dan Seimbang Yang Timbul Dari Pemanfaatannya Atas Konvensi Keanekaragaman Hayati) ${ }^{25}$ yang di dalamnya mengatur pula pengetahuan tradisional yang terkait dengan sumber daya genetik, namun pemanfaatan pengetahuan tradisional pun perlu dilakukan mengingat banyaknya pengetahuan tradisional milik bangsa Indonesia yang dibajak oleh negara-negara maju tanpa adanya pembagian manfaat secara adil bagi Indonesia. Di sisi lain, pemanfaatan pengetahuan tradisional sendiri masih terbatas yaitu dilakukan secara sederhana oleh masyarakat lokal, antara lain jamu gendong dan obat-obatan tradisional. Pemanfaatan secara lebih modern hanya dilakukan oleh perusahaan besar yang juga tidak memberikan

${ }^{23}$ Agus Sardjono, Op. Cit., hal. 143.

${ }^{24}$ Republik Indonesia. Undang-Undang Nomor 11 Tahun 2013 Tentang Pengesahan Nagoya Protocol On Access To Genetic Resources And The Fair And Equitable Sharing Of Benefits Arising From Their Utilization To The Convention On Biological Diversity (Protokol Nagoya Tentang Akses Pada Sumber Daya Genetik Dan Pembagian Keuntungan Yang Adil Dan Seimbang Yang Timbul Dari Pemanfaatannya Atas Konvensi Keanekaragaman Hayati), Lembaran Negara Republik Indonesia Tahun 2013, Nomor 73 , Tambahan Lembaran Negara Republik Indonesia Nomor 5412, Penjelasan Umum.

${ }^{25}$ Republik Indonesia. Loc. Cit. 
pembagian manfaat yang adil kepada masyarakat lokal yang memiliki pengetahuan tradisional tersebut.

Dengan mempertimbangkan karakteristik dan kondisi geografis Indonesia yang beragam, maka antara daerah di Indonesia memiliki potensi pengetahuan tradisional yang beragam pula. Potensi keberagaman yang dimiliki tiap daerah ini dapat dimanfaatkan dalam rangka mendukung pembangunan berkelanjutan yang dikembangkan oleh Indonesia. Pemanfaatan pengetahuan tradisional yang tepat dengan menilik pada kondisi Indonesia tersebut adalah jelas dapat menguntungkan daerah dan pusat, serta memiliki potensi keuntungan ekonomis. Pemanfaatan ini antara lain dapat dilakukan dengan memberdayakan potensi setiap daerah yang beragam tersebut dengan melibatkan partisipasi masyarakat lokal. Konsep ini sejalan dengan arahan Rencana Pembangunan Jangka Panjang Nasional (“RPJPN") 2005-2025 yang tertuang di dalam UU No.17 Tahun $2007^{26}$ yang juga mengamanatkan RPJP Daerah, bahwa pembangunan harus mengacu pada karakteristik masyarakat dan potensi masing-masing daerah di Indonesia dengan konsep pembangunan berkelanjutan. ${ }^{27}$ Pemanfaatan pengetahuan tradisional secara tepat (efektif dan efisien) dan benar berdasarkan karakteristik dan potensi daerah-daerah di Indonesia diharapkan dapat menjadi alternatif dalam mengembangkan perekonomian dan pembangunan di daerah tersebut yang secara tidak langsung hasilnya akan berdampak terhadap pembangunan Indonesia.

\section{Potensi Daerah dan Pengetahuan Tradisional Indonesia}

Potensi daerah merupakan seluruh kemampuan yang ada di daerah Indonesia (Provinsi dan Kabupaten/Kota) yang dapat dikembangkan menjadi sumber penghidupan masyarakat setempat. ${ }^{28}$ Potensi daerah yang dimaksud adalah potensi-potensi yang dimiliki setiap daerah dalam mendukung pemanfaatan pengetahuan tradisional yang dimiliki oleh tiap daerah tersebut yaitu antara lain potensi sumber daya alam, potensi sumber daya manusia, potensi lingkungan, dan potensi infrastruktur. ${ }^{29}$ Setiap daerah memiliki perbedaan terkait karakteristik potensi sumber daya alamnya. Di satu daerah sumber daya alamnya sudah tereksplorasi, sementara di daerah belum tereksplorasi bahkan belum terjamah sama sekali. Kondisi lain, sumber daya manusia cukup baik di suatu daerah, sementara di daerah lain baik dari segi

${ }^{26}$ Republik Indonesia .Undang-Undang Nomor 17 Tahun 2007 Tentang Rencana Pembangunan Jangka Panjang Nasional Tahun 2005 -2015, Lembaran Negara RI Tahun 2007 Nomor 33, Tambahan Lembaran Negara RI Nomor 4700.

${ }^{27}$ PKPU, “Indeks Potensi Daerah Indonesia 2013”, (Jakarta: PKPU - P3M UI, 2013) hal. 1.

\footnotetext{
${ }^{28}$ Ibid., hal. 4.

${ }^{29}$ Ibid.
} 
kualitas maupun kuantitasnya sumber daya manusia yang dimiliki tidak memadai. Begitu halnya dengan kondisi infrastruktur di tiap daerah yang juga tidak sama, ada yang sudah baik dan ada yang karena kondisi geografisnya berupa wilayah kepulauan atau daerah terpencil, kondisi infrastrukturnya tidak mendukung. ${ }^{30}$ Termasuk juga sumber daya lingkungan seperti hutan, danau, sungai, adat istiadat yang berbeda-beda di tiap daerah yang kesemuanya menjadi potensi kekayaan yang bisa digunakan untuk memanfaatkan pengetahuan tradisional daerah-daerah di Indonesia.

Sumber daya manusia merupakan potensi yang terkandung di dalam diri manusia untuk mewujudkan perannya sebagai makhluk sosial yang adaptif dan transformatif yang oleh karenanya dapat memberdayakan dirinya sendiri serta potensi yang terkandung di alam menuju tercapainya kesejahteraan kehidupan dalam tatanan yang seimbang dan berkelanjutan. Potensi sumber daya manusia dapat dilihat dari aspek fisik yang meliputi kesehatan, kebugaran, kualitas fisik tempat tinggal dan aspek non-fisik yang meliputi kemampuan berfikir dan tingkat keterampilannya. ${ }^{31}$ Sumber daya manusia ini berperan penting dalam upaya pemanfaatan pengetahuan tradisional karena merujuk kepada RPJP Nasional dan RPJP Daerah, partisipasi masyarakat menjadi bagian penting dalam proses pembangunan. Masyarakat indonesia pun memiliki kemampuan berfikir dan keterampilan yang berbeda terkait pemanfaatan pengetahuan tradisional di bidang pertanian, ilmiah, lingkungan, obat-obatan termasuk di dalamnya obat dan penyembuhan dan keanekaragaman hayati. Kemampuan dan keterampilan tersebut sangat tergantung pada daerah mana masyarakat itu bermukim. Oleh karenanya, pemberdayaan sumber daya manusia yang didasarkan karakteristik dan potensi daerah berguna agar pemanfaatan pengetahuan tradisional bisa efektif dan efisien.

Sumber daya lingkungan mencakup lingkungan fisik yaitu lingkungan geografis suatu wilayah yang dibatasi oleh batas administratif suatu wilayah pemerintahan dan lingkungan sosial yang mencakup komunitas masyarakat atau penduduk termasuk adat istiadat perilaku atau kebiasaan serta pranata sosial yang ada di wilayah tersebut. Indonesia kaya akan keanekaragaman suku bangsa, tercatat oleh Badan Pusat Statistik sebanyak 1.340 suku bangsa yang dimiliki Indonesia. ${ }^{32}$ Potensi keanekaragaman suku bangsa ini dapat digambar berdasarkan pulau sebagai berikut:

\begin{tabular}{|c|l|c|}
\hline O & \multicolumn{1}{|c|}{ PULAU } & \multicolumn{1}{c|}{ SUKU BANGSA } \\
\hline & Jawa & $\begin{array}{l}\text { Jawa (termasuk Suku Bawean, Suku } \\
\text { Tengger, Suku Osing dan lain-lain); }\end{array}$ \\
\hline
\end{tabular}

${ }^{30}$ Ibid.

${ }^{31}$ Ibid., hal. 28.

$32<$ http://id.wikipedia.org/wiki/Suku_bangsa_di_Indonesia>, diakses pada tanggal 27 Desember 2013. 


\begin{tabular}{|l|l|l|}
\hline & - Sunda (termasuk Suku Baduy); \\
& & - Banten; \\
- Cirebon; \\
\hline - Betawi.
\end{tabular}

Sumber: http://id.wikipedia.org/wiki/Suku_bangsa_di_Indonesia

Masyarakat-masyarakat adat (suku bangsa) tersebut memiliki dan masih melestarikan bahasa, kesenian, kerjainan tangan, obat tradisonal dari alam, proses penyembuhan, proses memasak, proses pemanfaatan alam, dan lain sebagainya yang bernilai ekonomis. Di beberapa suku bangsa di dunia, pengetahuan tradisional telah menjadi bagian kehidupannya yang yang digunakan dan dilestarikan bahkan pengetahuan tradisional tersebut telah menjadi identitas budaya yang bernilai suci dari suku bangsa tersebut antara lain : penyembuh tradisional (dukun) Thailand menggunakan Plao-Noi untuk mengobati bisul, Suku San (Southern Africa) menggunakan kaktus Hoodia untuk mencegah kelaparan pada saat keluar berburu, irigasi berkelanjutan 
dilestarikan melalui sistem air tradisional yang disebut Aflaj (Oman dan Yaman), dan Qanat di Iran; Orang Cree dan Inuit (Canada) melestarikan pengetahuan unik mengenai pola migrasi musiman spesies tertentu di wilayah Teluk Hudson, dan penyembuh Adat di Amazon Barat menggunakan anggur Ayahuasca sebagai obat-obatan yang memiliki nilai kesucian bagi adat tersebut. $^{33}$

Sementara masyarakat adat Indonesia juga telah menggunakan dan melestarikan pengetahuan tradisional yang didapatkannya secara turun temurun. Namun demikian pemanfaatan yang dilakukan masih terbatas pada daerah atau untuk sukunya saja, dan belum dimanfaatkan secara luas oleh pemerintah daerah untuk mendatangkan keuntungan ekonomis. Salah satu contoh produk pengetahuan tradisional yang telah dimanfaatkan dan bernilai ekonomis adalah batik, yang dibuat berdasarkan pengetahuan tradisional berupa teknik pembuatan batik secara tulis maupun stempel (cap). Batik ini sudah dikenal di dunia sebagai warisan budaya Indonesia, namun nyatanya banyak negara yang mencoba memanfaatkan pengetahuan tradisional ini untuk mendapatkan keuntungan di negaranya seperti Malaysia dan Singapura.

Sumber daya infrastruktur secara sempit diartikan sebagai fasilitas fisik berupa sarana dan prasarana maupun sarana fisik yang dibangun dalam rangka memenuhi kebutuhan dan meningkatkan kesejahteraan masyarakat. ${ }^{34}$ Potensi sumber daya infrastruktur mencakup : (1) fasilitas ekonomi yaitu fasilitas yang dibangun dalam rangka memenuhi kebutuhan ekonomi masyrakat; (2) fasilitas kesehatan yaitu fasilitas yang dibangun untuk memenuhi kebutuhan masyarakat akan pelayanan kesehatan; (3) fasilitas pendidikan yaitu fasilitas yang dibangun dalam rangka memenuhi kebutuhan masyarakat akan pelayanan pendidikan; (4) fasilitas keagamaan yaitu fasilitas yang dibangun dalam rangka memenuhi kebutuhan masyarakat menjalankan kegiatan ibadahnya seperti rumah ibadah; dan (5) fasilitas perhubungan yaitu fasilitas yang dibangun dalam rangka memenuhi kebutuhan masyarakat akan pelayanan transportasi. ${ }^{35}$ Fasilitas yang ada di tiap daerah ini berperan penting penghubung sekaligus media bagi masyarakat untuk mengembangkan dan memanfaatkan potensi pengetahuan tradisional yang dimilikinya sehingga pengetahuan tersebut dapat mendatangkan keuntungan ekonomis bagi masyarakat daerah tersebut.

Sumber daya alam adalah segala sesuatu yang muncul secara alami yang dapat digunakan untuk pemenuhan kebutuhan manusia pada umumnya yang terdiri atas sumber daya alam yang dapat diperbaharui (renewable resources) dan sumber daya alam yang tidak dapat diperbaharui (non-renewable resources) atau berdasarkan sifatnya terdiri sumber daya alam hayati dan

${ }^{33}$ World Intellectual Property Organization, Intellectual Property and Traditional Knowledge, Booklet. diakses melalui <www.wipo.int>, diakses tanggal 26 Desember 2013.

\footnotetext{
${ }^{34}$ PKPU, Op. Cit., hal. 110.

${ }^{35}$ Ibid., hal. 111.
} 
sumber daya alam non-hayati. ${ }^{36}$ Indonesia merupakan negara yang memiliki kekayaan alam hayati dan non-hayati yang melimpah, namun keberadaaannya tidak tersebar merata di seluruh daerah di Indonesia. Berdasarkan data dari Kementerian Kelautan dan Perikanan, Indonesia memiliki 450 (empat ratus lima puluh) spesies terumbu karang dari 700 (tujuh ratus) spesies dunia. ${ }^{37}$ Lembaga Ilmu Pengetahuan Indonesia pada tahun 2011 dalam terbitannya mengenai Status Keanekaragaman Hayati Indonesia, mencatat bahwa Indonesia memiliki keragaman spesies antara lain: ${ }^{38}$

1. 707 (tujuh ratus tujuh) spesies mamalia;

2. 1.602 (seribu enam ratus dua) spesies burung;

3. 1.112 (seribu seratus dua belas) spesies amfibi dan reptil;

4. 2.800 (dua ribu delapan ratus) spesies invertebrata;

5. 1.400 (seribu empat ratus) spesies ikan;

6. 35 (tiga puluh lima) spesies primata; dan

7. 120 (seratus dua puluh) spesies kupu-kupu.

Di samping itu Indonesia merupakan negara berkembang yang masih mengandalkan pembangunan dari sektor pertanian. Dari data yang tersedia, keaneragaman pertanian Indonesia juga menjadi salah satu potensi sumber daya alam, khususnya yang berhubungan dengan pengetahuan tradisional masyarakat lokal dalam mengelola pertanian. Dari 33 provinsi di Indonesia, hanya DKI Jakarta yang tidak mengandalkan pembangunan dari sektor pertanian. Data potensi daerah yang mengandalkan sektor pertanian dapat disajikan sebagai berikut:

\begin{tabular}{|c|l|c|}
\hline NO & \multicolumn{1}{|c|}{ PROVINSI } & $\begin{array}{c}\text { PERTANI } \\
\text { AN } \\
\text { (PERSEN } \\
\text { TASE) }\end{array}$ \\
\hline 1 & Papua & 97.25 \\
\hline 2 & Sulawesi Barata & 97.02 \\
\hline 3 & Papua Barat & 95.97 \\
\hline 4 & Nusa Tenggara Timur & 95.52 \\
\hline 5 & Maluku & 94.34 \\
\hline 6 & Kalimantan Barat & 94.05 \\
\hline 7 & Sulawesi Tengah & 93.94 \\
\hline 8 & Kalimantan Tengah & 93.46 \\
\hline 9 & Lampung & 93.43 \\
\hline 10 & Aceh & 92.81 \\
\hline
\end{tabular}

${ }^{36}$ Ibid., hal. 43.

${ }^{37}$ Republik Indonesia. Undang-Undang Nomor 11 Tahun 2013 Tentang Pengesahan Nagoya Protocol On Access To Genetic Resources And The Fair And Equitable Sharing Of Benefits Arising From Their Utilization To The Convention On Biological Diversity, Ibid.

${ }^{38}$ Ibid. 


\begin{tabular}{|c|l|c|}
\hline 11 & Bengkulu & 92.38 \\
\hline 12 & Maluku Utara & 92.22 \\
\hline 13 & Jambi & 91.62 \\
\hline 14 & Sumatera Selatan & 90.83 \\
\hline 15 & Sulawesi Tenggara & 90.57 \\
\hline 16 & Nusa Tenggara Barat & 89.76 \\
\hline 17 & Sulawesi Selatan & 89.37 \\
\hline 18 & Kalimantan Selatan & 89.15 \\
\hline 19 & Gorontalo & 89.06 \\
\hline 20 & Riau & 89.00 \\
\hline 21 & Sulawesi Utara & 88.66 \\
\hline 22 & Sumatera Utara & 88.56 \\
\hline 23 & Jawa Tengah & 85.95 \\
\hline 24 & Kalimantan Timur & 85.87 \\
\hline 25 & Jawa Timur & 85.74 \\
\hline 26 & Sumatera Barat & 81.22 \\
\hline 27 & Yogyakarta & 81.05 \\
\hline 28 & Jawa Barat & 77.83 \\
\hline 29 & Bali & 77.09 \\
\hline 30 & Kepulauan Riau & 74.22 \\
\hline 31 & Banten & 73.49 \\
\hline 32 & Bangka Belitung & 60.11 \\
\hline 33 & DKI Jakarta & 2.62 \\
\hline
\end{tabular}

Sumber: PKPU: Indeks Potensi Daerah Indonesia 2013

Komoditi hasil pertanian yang diandalkan oleh daerah-daerah di Indonesia tersebut meliputi padi, palawija, hortikultura, perkebunan, pertenakan, perikanan tangkap, perikanan budidaya, kehutanan, dan jasa pertanian. Namun, komiditi yang miliki potensi untuk dikembangkan dan dimanfaatkan, dalam hal ini yang berkaitan dengan pengetahuan tradisional di bidang pertanian antara lain: padi, palawija, hortikultura, perkebunan dan pertenakan. Pemanfaatan pengetahuan tradisional yang berkaitan dengan pertanian antara lain dalam pengetahuan tradisional mengenai penggunaan tanaman, strategi pelestarian tanaman, hama (pest) dan penyembuhan penyakit, pengawasan lingkungan terhadap perubahan ekologi, dan seleksi tradisional serta metode-metode pemuliaan tanaman. ${ }^{39}$

Dari data yang disajikan di atas menunjukkan begitu kayanya Indonesia dengan keanekaragaman hayatinya yang tinggi serta memiliki keanekaragaman sumber daya genetik dan ekosistem dengan karakteristik tertentu. Pengetahuan tradisional yang berkaitan dengan sumber daya genetik dan pertanian yang dimiliki Indonesia tersebut sangat rentan untuk dicuri dan disalahgunakan oleh

${ }^{39}$ Cita Citrawinda Priapantja, "Hak Kekayaan Intelektual : Tantangan Masa Depan”, (Jakarta: Badan Penerbit Fakultas Hukum Universitas Indonesia, 2003), hal. 136. 
pihak asing tanpa memberikan manfaat kepada bangsa Indonesia. Amerika Serikat dan Jepang menjadi contoh negara yang melakukan biopiracy dan missappropriation terhadap pengetahuan tradisional Indonesia. 14 obat penting yang dipatenkan di Amerika Serikat berasal dari tumbuhan Indonesia antara lain "tapak dara" yang berguna bagi penyembuhan kanker sementara Jepang mematenkan obat-obatan dan kosmetika yang bahannya diperoleh dari keanekaragaman dan pengetahuan tradisional Indonesia. ${ }^{40}$ Oleh karenanya, pemanfaatan pengetahuan tradisional atas kekayaan hayati tersebut perlu dilakukan untuk mendapatkan manfaat ekonomis bagi masyarakat lokal yang memiliki pengetahuan tersebut serta untuk mencegah tindakan pencurian (biopiracy) dan penyalahgunaan (missappropriation) pengetahuan tradisional masyarakat lokal Indonesia oleh pihak asing, dalam hal ini negara-negara maju yang telah memiliki dan mengembangkan bioteknologi.

\section{Pemanfaatan Pengetahuan Tradisional sebagai Modal Pembangunan}

Indonesia adalah negara berkembang yang berada di garis terdepan dalam memberikan pengakuan terhadap perlindungan HKI secara internasional. Indonesia telah menandatangani Persetujuan TRIPs yang menjadi satu kesatuan dengan Pembentukan WTO dan telah diratifikasi tanpa reservasi (full compliance) melalui Undang-undang No. 7 Tahun $1994 .^{41}$ Indonesia telah melahirkan berbagai peraturan perundang-undangan sebagai komitmen sekaligus kosekuensi penandatanganan dan peratifikasian TRIPs yaitu antara lain UU RI No. 30 Tahun 2000 tentang Rahasia Dagang, ${ }^{42}$ UU RI No. 31 Tahun 2000 tentang Desain Industri, ${ }^{43}$ UU RI No. 32 Tahun 2000 tentang Desain Tata Letak Sirkuit Terpadu, ${ }^{44}$ UU RI No. 14 Tahun 2001 tentang Paten, ${ }^{45}$ UU RI No. 15 Tahun 2001 tentang Merek, ${ }^{46}$ dan UU RI No.19 Tahun 2002 tentang Hak Cipta. ${ }^{47}$

${ }^{40}$ Agus Sardjono, Op. Cit., hal. 3.

${ }^{41}$ Undang-Undang Republik Indonesia Nomor 7 Tahun 1994 Tentang Pengesahan Agreement Establishing The World Trade Organization (Persetuajuan Pembentukan Organisasi Perdagangan Dunia), Lembaran Negara RI Tahun 1994 Nomor 57, Tambahan Lembaran Negara RI Nomor 3564.

42 Republik Indonesia, Undang-Undang Nomor 30 Tahun 2000 tentang Rahasia Dagang, Lembaran Negara RepubIik Indonesia Tahun 2000, No. 242, Tambahan Lembaran Negara No. 4044.

43 Republik Indonesia, Undang-Undang Nomor 31 Tahun 2000 tentang Desain Industri Lembaran Negara Republik Indonesia Tahun 2000, No. 243, Tambahan Lembaran Negara No. 4045.

44 Republik Indonesia, Undang-Undang Nomor 32 Tahun 2000 tentang Desain tataletak Sirkuit Terpadu Lembaran Negara RepubIik Indonesia Tahun 2000, No. 244, Tambahan Lembaran Negara No. 4046. 
Namun demikian, sebagaimana telah diuraikan di muka, bahwa rezim HKI yang diatur di dalam perundang-undangan Indonesia merupakan hasil desakan negara-negara maju yang tidak mengakui adanya hak milik komunal atas pengetahuan tradisional dari negara-negara berkembang, termasuk Indonesia. Pengaturan terbatas mengenai pengakuan hak komunal (masyarakat lokal) Indonesia dapat dijumpai di dalam UU No. 29 Tahun 2000 tentang Perlindungan Varietas Tanaman, ${ }^{48}$ hak atas foklor di dalam UU No. 19 Tahun 2002 dan hak atas indikasi geografis di dalam UU No. 15 Tahun 2001. Indonesia belum memiliki undang-undang sui generis yang mengatur perlindungan dan pemanfaatan pengetahuan tradisional. Sementara kekayaan pengetahuan tradisional Indonesia begitu melimpah dan beragam di antaranya pengetahuan tradisional yang terkait dengan sumber daya genetik, pertanian, ilmiah, lingkungan obat-obatan, kosmetika, ekpresi foklor di bidang musik, tari, lagu, kerajinan tangan, unsur-unsur bahasa, dan benda budaya yang bergerak lainnya yang dimiliki oleh daerah secara beragam. Oleh karenanya, pemanfaatan yang seimbang dan berkelanjutan dengan mendasarkan pada potensi-potensi yang dimiliki oleh daerah maka akan menghasilkan efektifitas dan efisiensi pemanfaatan engetahuan tradisional yang dapat mendukung pembangunan daerah khususnya dan pembangunan Indonesia secara keseluruhan.

Pemanfaatan pengetahuan tradisional berdasarkan karakteristik dan potensi daerah tersebut sesuai dengan konsep pembangunan Indonesia yang dituangkan di dalam RPJP Nasional 2005-2025. Selain mengatur RPJP Nasional, UU No. 17 Tahun 2007 juga mengatur RPJP Daerah dalam rangka membangun daerah sesuai karakteristik dan potensi yang dimilikinya. Konsep pembangunan yang digunakan Indonesia dalam RPJP Nasional dan RPJP Daerah tersebut adalah pembangunan berkelanjutan (sustainable development) yang memiliki prinsip dasar "memenuhi kebutuhan sekarang tanpa mengorbankan pemenuhan kebutuhan generasi masa depan. ${ }^{49}$ Lebih jelasnya di dalam UU No. 17 Tahun 2007 tentang RPJPN 2005-2025 dikatakan bahwa pelaksanaan pembangunan nasional dilakukan dalam konteks memenuhi kebutuhan masa sekarang tanpa mengurangi kemampuan generasi yang akan datang untuk memenuhi kebutuhannya. ${ }^{50}$ Konsep pembangunan berkelanjutan

45 Republik Indonesia, Undang-Undang Nomor 14 Tahun 2001 tentang Paten Lembaran Negara Republik Indonesia Tahun 2001, No. 109, Tambahan Lembaran Negara No. 4130 .

46 Republik Indonesia, Undang-Undang Nomor 15 Tahun 2001 tentang Merek Lembaran Negara Republik Indonesia Tahun 2001, No. 110, Tambahan Lembaran Negara No. 4131 .

${ }^{47}$ Republik Indonesia, Undang-Undang Nomor 19 Tahun 2002 tentang Hak Cipta Lembaran Negara RI Tahun 2002, No. 85, Tambahan Lembaran Negara No. 4220

${ }^{48}$ Republik Indonesia, Undang-Undang Nomor 29 Tahun 2000 tentang Perlindungan Varietas Tanaman, Lembaran Negara RI Tahun 2000, No.241, Tambahan Lembaran Negara No. 4043.

${ }^{49}$ PKPU. Op cit, hal. 2. 
mencakup tiga pilar penting kebijakan pembangunan yaitu pembangunan ekonomi, pembangunan sosial, dan pembangunan lingkungan. ${ }^{51}$ Pembangunan berkelanjutan menginginkan adanya keseimbangan antara pemanfaatan, keberlanjutan, keberadaaan, dan kegunaan sumber daya alam dan lingkungan hidup dengan tetap menjaga fungsi, daya dukung dan kenyamanan dalam kehidupan masa kini dan masa yang akan datang. ${ }^{52}$

Pengembangan konsep pembangunan di daerah-daerah dewasa ini adalah pembangunan yang berorientasi pada manusia (Apurtham, 2008). ${ }^{53}$ Artinya dalam pembangunan yang dilaksanakan di daerah melibatkan partisasi masyarakat. Hal ini sesuai dengan isi penjelasan UU No. 17 tahun 2007 yang menginginkan partisipasi masyarakat dalam pembangunan. Dalam konsep pembangunan ini, rakyat diperlakukan sebagai subyek yang aktif dan bukan sebagai obyek pembangunan. Pembangunan berkelanjutan juga menghendaki keterlibatan semua elemen bangsa, masyrakat, pemerintah, lembaga negara, organisasi kemasyarakatan dan politik. Oleh karenanya, sinergitas antara pemanfaatan pengetahuan tradisional dengan potensi daerah yang melibatkan partisipasi masyarakat akan menjadi modal daerah dalam mendorong pertumbuhan yang berkelanjutan (development sustainability) di daerah tersebut. Atau dengan kata lain, pemanfaatan pengetahuan tradisional berdasarkan potensi yang dimiliki daerah dapat menciptakan peluang usaha dan dapat mempengaruhi perekonomian serta pembangunan di daerah tersebut. $^{54}$

Pemanfatan pengetahuan tradisional berdasarkan potensi daerah diperlukan setidaknya karena 3 (tiga) alasan. Pertama, keanekaragaman yang dimiliki Indonesia baik yang hayati maupun budaya sangat melimpah. Antara satu daerah dengan daerah lain memiliki karakteristik dan potensi yang beragam. Karakteristik dan potensi tersebut memiliki nilai ekonomis untuk dimanfaatkan melalui cara-cara yang tepat dan benar. Kedua, adanya pengaturan HKI di satu sisi menjadi pintu masuk negara-negara maju untuk dapat mengakses sumber daya genetik, pengetahuan tradisional dan foklor Indonesia. TRIPs memberlakukan asas non-diskriminasi yang mengatur larangan perlakuan yang diskriminatif dari sebuah negara terhadap inventor dari negara lain yang hendak mendaftarkan patennya di negara tersebut meskipun paten yang didaftarkan didapatkan dari hasil penelitian dan pemanfaatan sumber daya genetik, pengetahuan tradisional dan foklor negara tersebut. Negara-negara maju dapat melakukan tindakan pemanfaatan kekayaan intelektual masyarakat di negara-negara berkembang melalui tindakan pencurian maupun penggunaan tanpa hak.Pemanfaatan pengetahuan

$$
\begin{aligned}
& { }^{50} \text { Ibid. } \\
& { }^{51} \text { Ibid., hal. } 12 . \\
& { }^{52} \text { Ibid., hal. } 2 . \\
& { }^{53} \text { Ibid., hal. } 9 . \\
& { }^{54} \text { Ibid., hal. } 4 .
\end{aligned}
$$


tradisional setidaknya untuk mencegah tindakan-tindakan tersebut. Ketiga, pengetahuan tradisional merupakan cultural identity atau identitas budaya sebuah masyarakat atau sebuah suku bangsa. Pemanfaatan pengetahuan tradisional merupakan bentuk upaya melestarikan kebudayaan Indonesia.

Pemanfaatan pengetahuan tradisional sebagai modal pembangunan pertama kali dilakukan dengan mengiventarisasi potensi-potensi yang dimiliki oleh tiap daerah antara lain potensi pengetahuan tradisional yang berkaitan dengan sumber daya manusia, sumber daya alam, lingkungan, dan infrastruktur. Dengan terinventarisasinya potensi pengetahuan tradisional tersebut, maka langkah selanjutnya adalah membuat perencanaan pemanfaatan dan pelaksanaan pemanfaatan yang melibatkan partisipasi masyarakat dalam arti luas. Keterlibatan masyarakat di dalam pemanfaatan pengetahuan tradisional antara lain dapat dilakukan melalui metode kerjasama, baik antara perusahaan, peneliti, pemerintah, dan masyarakat lokal. Metode ini diterapkan di New Zealand antara masyarakat Maori dengan Cancer Genetics Research Team dari University of Otago yang dikenal dengan Kimihauora Trust. Kerjasamana ini dilakukan dengan metode pemberian informasi dari masyarakat Maori mengenai genealogical and medical information kepada peneliti yang kemudian hasilnya akan dimanfaatkan untuk mengobati penyakit kanker dan didaftarkan dengan rezim paten sehingga masyarakat Maori mendapatkan keuntungan ekonomis dan secara penuh didukung oleh $\mathrm{New}$ Zealand Gastroenterologist Association and New Zealand Health Research Council. $^{55}$

Pemerintah baik pusat maupun daerah juga mempunyai peran penting dalam hal membuat kebijakan yang tepat serta menyiapkan sarana dan prasarana dalam mendukung pemanfaatan pengetahuan tradisional berdasarkan potensi sumber daya manusia, sumber daya alam, lingkungan, dan infrastruktur yang dimiliki daerah tersebut. Sementara lembaga swadaya masyarakat membantu masyarakat lokal dalam upaya pemanfatan pengetahuan tradisional melalui pelatihan maupun advokasi yang bertujuan memberdayakan masyarakat sehingga masyarakat bisa mengelola dan memanfaatkan pengetahuan tradisional yang dimilikinya secara maksimal dan mendatangkan keuntungan ekonomis bagi masyarakat yang bersangkutan. Bekerjanya sistem pemanfaatan pengetahuan tradisional ini, yang melibatkan seluruh elemen masyarakat, akan menggerakan pembangunan ekonomi, sosial, dan lingkungan suatu daerah sehingga hasil dari pembangunan tersebut dapat dinikmati juga oleh generasi mendatang. Hasil dari pembangunan inilah yang diharapkan oleh konsep pembangunan yang diinginkan UU No. 17 Tahun 2007. hal. 23-24.

${ }^{55}$ Agus Sardjono, "Hak Kekayaan Intelektual dan Pengetahuan Tradisional”, Op. Cit., 


\section{Penutup}

\section{Kesimpulan}

Pengetahuan tradisional Indonesia merupakan pengetahuan yang dimiliki dan digunakan oleh masyarakat maupun suku bangsa Indonesia yang didapatkannya secara turun temurun yang memiliki nilai ekonomis dan merupakan identitas budaya bangsa Indonesia. Di satu sisi perlindungan terhadap pengetahuan tradisional penting dilakukan untuk mencegah tindakan biopiracy dan juga missappropriation yang dilakukan negara-negara maju untuk mendapatkan keuntungan tanpa memberikan pembagian manfaat (benefit sharing) kepada masyarakat adat atau suku bangsa yang memiliki pengetahuan tradisional tersebut. Di sisi lain pemanfaatan pengetahuan tradisional sesungguhnya merupakan perlindungan pengetahuan tradisional itu sendiri. Setidaknya ada 3 (tiga) alasan pentingnya pemanfaatan pengetahuan tradisional yaitu antara lain: (1) pengetahuan tradisional memiliki nilai ekonomis sehingga akan mendatangkan keuntungan apabila dimanfaatkan secara tepat dan benar; (2) pemanfaatan bertujuan mencegah lebih lanjut tindakan biopiracy dan missappropriation yang dilakukan negara-negara maju; dan (3) Pengetahuan tradisional merupakan identitas budaya sebuah bangsa sehingga dengan memanfaatkan pengetahuan tradisional berarti melestarikan budaya bangsa Indonesia.

Kondisi geografis Indonesia yang terdiri dari kepulauan dan banyaknya suku bangsa di Indonesia menyebabkan potensi setiap daerah di Indonesia menjadi beragam. Karakteristik dan potensi daerah terkait dengan pengetahuan tradisional didasarkan pada sumber daya manusia, sumber daya alam, lingkungan, dan infrastruktur yang dimiliki oleh daerah tersebut. Pemanfaatan pengetahuan tradisional yang sinergi dengan potensi daerah akan menggerakkan pertumbuhan berkelanjutan di daerah dan menjadi modal pembangunan Indonesia. Langkah pertama pemanfaatan pengetahuan tradisional dilakukan dengan mengiventarisasi potensi dan karakteristik daerah antara lain potensi sumber daya manusia, sumber daya alam, lingkungan, dan infrastruktur. Pemanfaatan selanjutnya dengan melakukan perencanaan dan melakukan kerjasama dengan melibatkan partisipasi seluruh elemen bangsa baik peneliti, akademisi, pemerintah, lembaga swadaya masyarakat dan juga masyarakat yang bersangkutan yang memiliki pengetahuan tersebut untuk bisa dinikmati juga oleh generasi mendatang. Hal ini sejalan dengan konsep pembangunan berkelanjutan sebagaimana dicanangkan dalam UU No. 17 tahun 2007 tentang Rencana Pembangunan Jangka Panjang Nasional 2005 - 2025.

\section{Saran}

Berdasarkan kesimpulan tersebut, maka pemerintah baik pusat maupun daerah seharusnya menjalankan peran yang lebih kontributif 
terhadap upaya pemanfaatan pengetahuan tradisional daerahnya yaitu dengan membuat kebijakan terkait perlindungan dan pemanfaatan pengetahuan tradisional, memberdayakan masyarakatnya melalui berbagai pelatihan keterampilan, menginventarisasi potensi pengetahuan tradisional tiap daerah, menyediakan sarana dan prasarana pemanfaatan pengetahuan tradisional tersebut, dan mempromosikan pengetahuan tradisional Indonesia baik dalam forum nasional maupun internasional. Disamping itu bersama dengan elemen masyarakat lainnya, bekerja sama dalam memanfaatkan pengetahuan tradisional dengan memberikan keuntungan seimbang dan adil bagi masyarakat yang memiliki pengetahuan tradisional tersebut. 


\section{Daftar Pustaka}

\section{Buku}

Maskus, Keith E. Intellectual Property Rights in Global Economy, Washington DC: Institute for International Economics, 2000.

PKPU, Indeks Potensi Daerah Indonesia 2013, Jakarta: PKPU - P3M UI, 2013

Purba, Ahmad Zen Umar. Perjanjian TRIPs dan Beberapa Isu Strategis, cetakan ke-1, Jakarta - Bandung: Badan Penerbit FH UI dan PT. Alumni, 2011.

Priapantja, Cita Citrawinda. Budaya Hukum Indonesia Menghadapi Globalisasi Perlindungan Rahasia Dagang di Bidang Farmasi, Cetakan Ketiga, Jakarta: Chandra Pratama, 2005.

Priapantja, Cita Citrawinda. Hak Kekayaan Intelektual: Tantangan Masa Depan, Jakarta: Badan Penerbit Fakultas Hukum Universitas Indonesia, 2003.

Saidin, OK. Aspek Hukum Hak Kekayaan Intelektual (Intellectual Property Rights), cetakan kesepuluh, Jakarta: Raja Grapindo Persada, 2010.

Sardjono, Agus. Membumikan HKI di Indonesia, Bandung: CV. Nuansa Aulia, 2009.

Sardjono, Agus, Hak Kekayaan Intelektual \& Pengetahuan Tradisional, Bandung: PT. Alumni, 2010.

Usman, Rachmadi. Hukum Hak Atas Kekayaan Intelektual: Perlindungan dan Dimensi Hukumnya di Indonesia, Bandung: Alumni, 2003.

World Intellectual Property Organization. Intellectual Property and Traditional Knowledge, Booklet, WIPO Publication No. 920 (E).

\section{Peraturan Perundang-Undangan}

Republik Indonesia. Undang-Undang Republik Indonesia Nomor 5 Tahun 1994 tentang Pengesahan United Nations Convention Konvensi Perserikatan Bangsa-Bangsa Mengenai Keanekaragaman Hayati, Lembaran Negara Tahun 1994 Nomor 41, Tambahan Lembaran Negara Nomor 3556.

Republik Indonesia. Undang-Undang Nomor 11 Tahun 2013 Tentang Pengesahan Nagoya Protocol On Access To Genetic Resources And The Fair And Equitable Sharing Of Benefits Arising From Their Utilization To The Convention On Biological Diversity (Protokol Nagoya Tentang Akses Pada Sumber Daya Genetik Dan Pembagian Keuntungan Yang Adil Dan Seimbang Yang Timbul Dari Pemanfaatannya Atas Konvensi Keanekaragaman Hayati), Lembaran Negara Republik Indonesia Tahun 
2013, Nomor 73, Tambahan Lembaran Negara Republik Indonesia Nomor 5412, Penjelasan Umum.

Republik Indonesia .Undang-Undang Nomor 17 Tahun 2007 Tentang Rencana

Pembangunan Jangka Panjang Nasional Tahun 2005-2015, Lembaran

Negara RI Tahun 2007 Nomor 33, Tambahan Lembaran Negara RI Nomor 4700.

Republik Indonesia. Undang-Undang Nomor 7 Tahun 1994 Tentang Pengesahan Agreement Establishing The World Trade Organization (Persetuajuan Pembentukan Organisasi Perdagangan Dunia), Lembaran Negara RI Tahun 1994 Nomor 57, Tambahan Lembaran Negara RI Nomor 3564.

Republik Indonesia, Undang-Undang Nomor 30 Tahun 2000 tentang Rahasia Dagang, Lembaran Negara Republik Indonesia Tahun 2000, No. 242, Tambahan Lembaran Negara No. 4044.

Republik Indonesia, Undang-Undang Nomor 31 Tahun 2000 tentang Desain Industri Lembaran Negara Republik Indonesia Tahun 2000, No. 243, Tambahan Lembaran Negara No. 4045.

Republik Indonesia, Undang-Undang Nomor 32 Tahun 2000 tentang Desain tataletak Sirkuit Terpadu Lembaran Negara Republik Indonesia Tahun 2000, No. 244, Tambahan Lembaran Negara No. 4046.

Republik Indonesia, Undang-Undang Nomor 14 Tahun 2001 tentang Paten Lembaran Negara Republik Indonesia Tahun 2001, No. 109, Tambahan Lembaran Negara No. 4130.

Republik Indonesia, Undang-Undang Nomor 15 Tahun 2001 tentang Merek Lembaran Negara Republik Indonesia Tahun 2001, No. 110, Tambahan Lembaran Negara No. 4131.

Republik Indonesia, Undang-Undang Nomor 19 Tahun 2002 tentang Hak Cipta Lembaran Negara RI Tahun 2002, No. 85, Tambahan Lembaran Negara No. 4220

Republik Indonesia, Undang-Undang Nomor 29 Tahun 2000 tentang Perlindungan Varietas Tanaman, Lembaran Negara RI Tahun 2000, No.241, Tambahan Lembaran Negara No. 4043.

\section{Karya Tulis dan Internet}

Aini, Desi Churul "Telaah Yuridis Ketentuan Perlindungan Pengetahuan Tradisional Dalam Hukum Internasional”, Tesis Pascasarjana Fakultas Hukum Universitas Indonesia, 2012.

WIPO, diakses melalui <http://www.wipo.int/tk/en/tk/index.html>, tanggal 26 Desember 2013. 
WIPO, diakses melalui <http://www.wipo.int/tk/en/igc/>, tanggal 26 Desember 2013.

WIPO, <http://www.wipo.int/wipolex/en/other_treaties/details.jsp?treaty_id= 311>, tanggal 26 Desember 2013.

Wikipedia, <http://id.wikipedia.org/wiki/Suku_bangsa_di_Indonesia〉, diakses pada tanggal 27 Desember 2013. 